\title{
Incidence and therapeutic strategies for the management of pulmonary papillary cell carcinoma
}

\author{
Alvaro Martin, Kassem Harris \\ Department of Medicine, Division of Pulmonary, Critical Care and Sleep Medicine, Interventional Pulmonology Section, Westchester Medical \\ Center, New York Medical College, Valhalla, NY, USA \\ Correspondence to: Kassem Harris, MD, FCCP. Department of Medicine. Division of Pulmonary, Critical Care and Sleep Medicine. Interventional \\ Pulmonology Section. Westchester Medical Center, New York Medical College, 100 Woods Road, Valhalla, New York 10595, USA. \\ Email: Kassemharris@gmail.com. \\ Provenance and Peer Review: This article was commissioned by the Editorial Office, Fournal of Thoracic Disease. The article did not undergo external peer review. \\ Comment on: Yuan Q, Sun N, Meng Z, et al. Pulmonary papillary squamous cell carcinoma: a population-based analysis of incidence, treatment, and \\ prognosis. J Thorac Dis 2019;11:4271-81.
}

Submitted Jan 05, 2020. Accepted for publication Feb 07, 2020.

doi: $10.21037 /$ jtd.2020.02.44

View this article at: http://dx.doi.org/10.21037/jtd.2020.02.44

We have read with great interest the paper by Yuan et al. (1). Here, they present what we found to be the largest composite of cases of papillary pulmonary squamous cell carcinoma (PSCC) available to date. It is also the first population-based analysis of this sporadic type of pulmonary squamous cell carcinoma (SCC). Apart from some small and anecdotal reports, the literature about this entity is scarce. Since 1967, the World Health Organization (WHO) has had a classification for lung malignancies. In 2004, the WHO classification recognized four different variants of SCC, among them was the pulmonary PSCC. Pulmonary PSCC was later removed from the classification in 2015 despite being considered to have enough unique features. Seemingly, they thought it is a very rare entity, and there was no prognostic significance of its classification (2).

In the literature, only a few authors have described the pulmonary papillary squamous cell carcinoma. Most of these reports date back to the 1950s and are in the form of small to medium size case series. In 1952, Liebow et al. published a case of papillomatosis of the larynx that extended distally to the trachea, which presented initially with hemoptysis. The presence of nuclear crowding and some occasional mitosis led them to describe it initially as a malignant lesion. After further review of similar cases, other authors found that it lacked enough characteristics to suggest malignancy (3). They concluded those features were more consistent with papilloma. Later, Dulmet-Brender et al. published what was considered for decades, the largest case series of patients with pulmonary endobronchial carcinomas and papillary features. They described 34 cases of grossly polypoid lesions that exhibit an exophytic growth pattern and malignant squamous epithelium. These characteristics are now the key differentiators between respiratory papilloma and pulmonary PSCC (4). In most of these cases, these lesions were at least partially obstructing the airway lumen, hence their symptomatology at earlier stages. During the 1960's, Smith et al. also described eight cases of papillary neoplasms of the bronchus with atypical cytological features (5). Similarly, Sherwin et al. reported nine lesions with endobronchial growth and papillomatous morphology. However, the most particular finding was the microscopical evidence of invasion, which suggested that these cancers could eventually spread. They did not find any metastasis (6). All the carcinomas reported in these papers shared multiple distinctive gross and microscopical features. They had papillary architecture; most of them were exophytic and had an endobronchial growth pattern.

Clinically, patients with pulmonary PSCC frequently present with central airway involvement, hence the development of early symptoms. The most described symptoms on presentation are indeed cough and hemoptysis, attributed primarily to this distinctive tumor growth pattern. Some patients may present with atelectasis or post obstructive pneumonia. Asymptomatic 
cases of pulmonary PSCC has been described and usually incidentally discovered on computed tomography (CT) chest imaging that is performed for other indications. Pulmonary PSCC do not usually present with evident abnormalities on chest films. During the 1950s and 1960s, the authors described these tumors as occult bronchial carcinoma (7). However, pulmonary PSCC tumors were still discovered at the early stage because patients developed symptoms. Bronchoscopy has been considered the gold standard for the diagnosis of pulmonary PSCC $(1,8)$.

Yuan et al. confirmed the very low incidence of pulmonary PSCC (1). Most probably, the incidence of pulmonary PSCC remained stable. However, because of the rarity of pulmonary PSCC, it is challenging to follow the incidence trend over the years. There is a possible correlation between human papilloma virus (HPV) and pulmonary PSCC, and data compiled from cancer registries reveal that the incidence rate of many HPVassociated cancers (such as oropharyngeal, anal, vulvar, and penile) has either remained stable or increased over the years (9). The association between papillomavirus and squamous cell carcinomas has been described, especially in immunocompromised patients. However, it remains unclear if HPV is associated with the development of pulmonary PSCC (10-14). Also, there was no convincing evidence of a clear causal relationship between smoking and pulmonary PSCC, which is the case for the rest of the pulmonary SCC.

There is no evidence of the neoplastic transformation of benign squamous papilloma to pulmonary PSCC. Only one case was reported in the literature by Bejui-Thivolet et al. They described pulmonary PSCC that developed at the site of condylomatous papilloma, and HPV type 11 was detected in the biopsy specimen (15). The pathological staging of lung cancer remains the most important prognostic factor.

As discussed by Yuan et al., pulmonary PSCC has a favorable prognosis when surgically treated at an earlier stage (1). However, there is no data to compare the prognosis pulmonary PSCC and SCC stage by stage. The NCCN guidelines for lung cancer categorize PSCC as a subtype of SCC based on pathological characteristics. There seem to be no implications on the treatment options. The management of SCC and its papillary subtype seems to be similar, and surgery is the gold standard at earlier stage (16). Targeted molecular therapy and immunotherapy have revolutionized cancer treatment, improving the survival of advanced-stage lung cancers (16). It is also true for squamous cell carcinoma with regimens that combined chemotherapy and immunotherapy, or targeted therapy based on the biopsy specimen analysis of PDL-1, EGFR, among other mutations. Again and because of the rarity of pulmonary PSCC, it would be probably treated like pulmonary SCC.

In conclusion, this study validates smaller reports about key characteristics of pulmonary PSCC, its rarity, prognosis, and outcome based on the management protocol. Prospective trials are needed for better outcome analysis, but given that pulmonary PSCC is extremely rare, such studies may not be feasible. For now, this paper by Yuan $e t a l$. highlighted the importance of surgery as the mainstay therapy of pulmonary PSCC. Chemotherapy is less effective, and radiotherapy worsens outcomes.

\section{Acknowledgments}

Funding: None.

\section{Footnote}

Conflicts of Interest: All authors have completed the ICMJE uniform disclosure form (available at http://dx.doi. org/10.21037/jtd.2020.02.44). The authors have no conflicts of interest to declare.

Ethical Statement: The authors are accountable for all aspects of the work in ensuring that questions related to the accuracy or integrity of any part of the work are appropriately investigated and resolved.

Open Access Statement: This is an Open Access article distributed in accordance with the Creative Commons Attribution-NonCommercial-NoDerivs 4.0 International License (CC BY-NC-ND 4.0), which permits the noncommercial replication and distribution of the article with the strict proviso that no changes or edits are made and the original work is properly cited (including links to both the formal publication through the relevant DOI and the license). See: https://creativecommons.org/licenses/by-nc-nd/4.0/.

\section{References}

1. Yuan Q, Sun N, Meng Z, et al. Pulmonary papillary squamous cell carcinoma: a population-based analysis of incidence, treatment, and prognosis. J Thorac Dis 2019;11:4271-81.

2. Kadota K, Nitadori JI, Woo KM, et al. Comprehensive pathological analyses in lung squamous cell carcinoma: 
single cell invasion, nuclear diameter, and tumor budding are independent prognostic factors for worse outcomes. J Thorac Oncol 2014;9:1126-39.

3. Liebow AA. Tumors of the lower respiratory tract. Armed Forces Institute of Pathology. Washington: Atlas of Tumor Pathology, 1952.

4. Dulmet-Brender E, Jaubert F, Huchon G. Exophytic endobronchial epidermoid carcinoma. Cancer 1986;57:1358-64.

5. Smith JF, Dexter D. Papillary neoplasms of the bronchus of low-grade malignancy. Thorax 1963;18:340-9.

6. Sherwin RP, Laforet EG, Strieder JW. Exophytic endobronchial carcinoma. J Thorac Cardiovasc Surg 1962;43:716-30.

7. Pearson FG, Thompson DW. Occult carcinoma of the bronchus. Can Med Assoc J 1966;94:825-33.

8. Cooper L, Hagenschneider JK, Banky S, et al. Papillary endobronchial squamous cell carcinoma. Ann Diagn Pathol 2005;9:284-8.

9. Van Dyne EA, Henley SJ, Saraiya M, et al. Trends in Human Papillomavirus-Associated Cancers - United States, 1999-2015. MMWR Morb Mortal Wkly Rep. 2018;67:918-24.

10. Imai H, Takahashi T, Taira T, et al. Papillary squamous

Cite this article as: Martin A, Harris K. Incidence and therapeutic strategies for the management of pulmonary papillary cell carcinoma. J Thorac Dis 2020;12(4):1283-1285. doi: $10.21037 /$ jtd.2020.02.44 cell carcinoma of the trachea associated with human papillomavirus-18 infection. Intern Med 2013;52:2785-8.

11. Benedetti MD, Marangi A, Bozzetti S, et al. HPV-related papillary squamous cell carcinoma of the tonsil during treatment with fingolimod. Mult Scler Relat Disord 2018;23:24-6.

12. Alagusundaramoorthy SS, Agrawal A. Respiratory papillomas. Lung India 2016;33:522-7.

13. Intakorn P, Sonsuwan N. Human papillomatosis genotyping and severity in patients with recurrent respiratory papillomatosis. J Med Assoc Thai 2014;97 Suppl 6:S136-41.

14. Silva EM, Mariano VS, Pastrez PRA, et al. Human papillomavirus is not associated to non-small cell lung cancer: data from a prospective cross-sectional study. Infect Agent Cancer 2019;14:18.

15. Bejui-Thivolet F, Chardonnet Y, Patricot LM. Human papillomavirus type 11DNA in papillary squamous cell lung carcinoma. Virchows Arch A Pathol Anat Histopathol 1990;417:457-61.

16. Ettinger DS, Wood DE, Aggarwal C, et al. NCCN Guidelines Insights: Non-Small Cell Lung Cancer, Version 1.2020. J Natl Compr Canc Netw 2019;17:1464-72. 